\title{
2 The Right to a Nationality as a Human RIGHT?
}

Mónika Ganczer*

\subsection{INTRODUCTION}

When interpreting the right to a nationality as a human right, one must take into account that matters of nationality fall within the domestic jurisdiction of states. Although human rights issues were removed from domestic jurisdiction, the right to a nationality as a human right is nevertheless pervaded by that nationality matters form part of the domaine réservé. This clearly manifests itself in the fact that its regulation on the international level reflects the interests of states, and the wording of relevant documents is typically vague and lacking in order to enable states to retain the regulation of nationality as far as possible within their respective domestic spheres. Thus, the right ensured on the international level is frequently rendered meaningless in practice. Divergent interpretations of its content also give rise to problems. It is believed that the right to a nationality should be construed as a right to one nationality, and as such, it includes the prohibition of dual nationality. ${ }^{1}$ Yet others urge the recognition of dual nationality as a human right. ${ }^{2}$ Personally, I do not share any of these views. I think that the right to a nationality is primarily meant to eliminate statelessness, since the right was originally created for this objective. The aim of the present study is to provide an overview of international instruments and documents containing the right to a nationality, to unveil the shortcomings of international regulation and to promote a better understanding of this particular right.

\subsection{Formulation of the Right to a Nationality}

The right to a citizenship as a precursor of the right to a nationality had emerged during the 16th century in a lecture of an outstanding member of the Spanish school of interna-

\footnotetext{
* Research fellow, Hungarian Academy of Sciences, Centre for Social Sciences, Institute for Legal Studies; Assistant professor, Széchenyi István University, Deák Ferenc Faculty of Law and Political Sciences. E-mail: ganczer.monika@tk.mta.hu.

1 W.L. Griffin, 'The Right to a Single Nationality', 40 Temple Law Quarterly (1966), p. 58.

2 P.J. Spiro, 'Dual Citizenship as a Human Right', 8(1) International Journal of Constitutional Law (2010), pp. 111-130.
} 
tional law, Francisco de Vitoria. He boldly claimed that certain persons 'cannot be excluded' from citizenship. ${ }^{3}$ However, the formulation of right to a nationality as a human right only took place in the mid-20th century. This right was first mentioned in a non-binding regional document, the American Declaration on the Rights and Duties of Man. ${ }^{4}$ The draft of the declaration was negotiated at a conference in Bogotá between 30 March and 2 May in 1948, parallel to the Charter of the Organization of American States, and was adopted on 2 May, eight months before the naissance of the Universal Declaration of Human Rights. The universal protection of the right to a nationality was envisaged by the Universal Declaration of Human Rights, ${ }^{5}$ adopted on 10 December 1948 by a resolution of the United Nations General Assembly, a non-binding document, which has since become binding as customary international law. ${ }^{6}$

The drafting process of the Universal declaration of Human Rights was certainly influenced by the American Declaration on the Rights and Duties of Man, which was attached as a background material. ${ }^{7}$ However, it is worth mentioning that the references to the right to a nationality, the change of nationality as well as to statelessness had already emerged at the beginning of the drafting in $1947 .^{8}$

The Chilean government presented the draft proposal of the Inter-American Juridical Committee, which included the right to a nationality, the prohibition of deprivation of nationality and the right to change nationality in June 1947.9 Subsequently, René Cassin submitted a detailed proposal containing the right to a nationality and ensuring the elimination of statelessness by member states of the United Nations, ${ }^{10}$ but the latter was not endorsed for incorporation into the Universal Declaration by other members of the Drafting Committee. In May 1948, India and the United Kingdom proposed an amendment, inter alia, to the article concerning nationality, in which the provision 'Everyone has the right to a nationality' was replaced by the phase 'No one shall be arbitrarily, deprived of

3 F. de Vitoria, 'De Indis prior Relectio', in F. de Vitoria (Ed.), Relectiones Theologicae, Manuel Martin, Matriti, 1765, p. 229.

4 American Declaration of the Rights and Duties of Man, O.A.S. Res. III, Ninth International Conference of American States, Bogotá, 2 May 1948.

5 The Universal Declaration of Human Rights, G.A. Res. 217A, 10 December 1948.

6 For more details with regard to Art. 15 see G.G. Schram, 'Article 15', in A. Eide et al. (Eds.), The Universal Declaration of Human Rights: A Commentary, Scandinavian University Press, Oslo, 1992, p. 233.

7 American Declaration on the Rights and Duties of Man, Commission on Human Rights, 3rd Session, E/CN.4/122, 10 June 1948.

8 A. Verdoodt, Naissance et signification de la Déclaration Universelle des Droits de l'Homme, E. Warny, Louvain, 1964, pp. 156-157.

9 Commission on Human Rights Drafting Committee, International Bill of Rights, E/CN.4/AC.1/3/Add.1, 11 June 1947. p. 273.

10 Commission on Human Rights, Drafting Committee on an International Bill of Human Rights, First Session, Report of the Drafting Committee to the Commission on Human Rights, E/CN.4/21, 1 July 1947. p. 61. 
his nationality. ${ }^{11}$ Peng-Chun Chang and Eleanor Roosevelt supported this text and stated that it was more preferable to guard persons against the arbitrary deprivation of nationality than to attempt to provide everyone the right to a nationality. The representative of Uruguay, Roberto Fontaina, concurred and suggested an amendment to the joint proposal by the delegations of India and United Kingdom that the declaration should contain the right to change of nationality similarly to the American Declaration. ${ }^{12}$ Therefore, the Commission on Human Rights adopted the following text: 'No one shall be arbitrarily deprived of his nationality or denied the right to change his nationality. ${ }^{13}$ Finally, in the course of the debate of the draft declaration in the Third Committee of the UN General Assembly, the right to a nationality was included into the text after the proposal by René Cassin dated 8 October $1948^{14}$ had been supported by a number of states, particularly by Cuba, Egypt, Lebanon and Uruguay. ${ }^{15}$ The proponents pointed out that the phrasing of deprivation of nationality was overly negative and the protection of stateless persons should enjoy priority. ${ }^{16}$

\subsection{Protection of Persons by the Right to a Nationality - Alternations in International Documents and Their INTERPRETATIONS}

Nationality matters falling within the domestic jurisdiction of states are limited by international law to such extent only as the state concerned undertakes international obligations pertaining to that matter. Even though nationality is governed in detail by domestic law, the domestic regulation of the right to a nationality is a rare phenomenon. The explicit mentioning of the right to a nationality appears in international documents instead: primarily in human rights documents and, to some extent, in international treaties concerning nationality. The interpretation and thorough analysis of these documents should be based upon a distinction of universal and regional protection of the right at issue.

11 India and the United Kingdom: Proposed Amendments to the Draft Declaration on Human Rights, Commission on Human Rights, 3rd Session, E/CN.4/99, 24 May 1948. p. 4.

12 Commission on Human Rights, Summary Record of the Fifty-Ninth Meeting, E/CN.4/SR.59, 10 June 1948. pp. 6-7.

13 Report of the Third Session of the Commission on Human Rights, E/800, 28 June 1948. p.12.

14 Draft International Declaration of Human Rights. France: Amendments to the Draft Declaration (E/800). Third Committee, 3rd Session, A/C.3/244, 8 October 1948. p. 1.

15 Draft International Declaration of Human Rights. Recapitulation of Amendments to Article 13 of the Draft Declaration (E/800). Third Committee, 3rd Session, A/C.3/286, 18 October 1948. pp. 1-2; Draft International Declaration of Human Rights. Recapitulation of Amendments to Article 13 of the Draft Declaration (E/800). Third Committee, 3rd Session, A/C.3/286/Rev.1, 30 October 1948. pp. 1-2.

16 Verdoodt, 1964, p. 159. 


\subsubsection{Universal Protection}

The universal protection of the right to a nationality commenced with the adoption of the Universal Declaration of Human Rights. Article 15 provides that everyone has the right to a nationality and states that no one shall be arbitrarily deprived of his or her nationality, nor denied of the right to change his nationality. ${ }^{17}$ Thus the right to a nationality is guaranteed to a wide group of persons, and the prohibition of arbitrary deprivation offers both protection against statelessness and a possibility to change nationality. Therefore, the Universal Declaration of Human Rights simultaneously recognizes the right to a nationality and the right to change nationality, and the prohibition of arbitrary deprivation of these rights. The formulation of the right to a nationality is vague and scanty, but it obviously strives to provide the right to acquire a nationality to stateless persons. One shortcoming of the text is that it fails to clarify which state has the obligation to grant nationality, and as such, the right to a nationality loses much of its importance. The wording of arbitrary deprivation of nationality and denying the right to change the nationality is equally inappropriate, as the expression 'arbitrary' is not defined. In accordance with the first paragraph, every deprivation of nationality that results in statelessness needs to be considered arbitrary, because it would not serve the purposes of the declaration. Furthermore, the right to change nationality needs to be interpreted so that the former state of nationality has an obligation to withdraw its nationality upon a request by a person who acquires another nationality. However, this right may easily become illusory. It cannot provide effective protection, if a person renounces his or her nationality, but is unable to acquire a new nationality.

The Declaration on the Rights of the Child of $1959^{18}$ was also adopted as a resolution of the UN General Assembly, but, unlike the Universal Declaration of Human Rights, it has never gained binding force. Principle 3 of this declaration only offers the 'child' the right to a nationality from his or her birth, ${ }^{19}$ in conformity with the limited scope of the document. At the meeting of the Third Committee of the UN General Assembly on 6 October 1959, Thailand suggested the deletion of this principle from the draft declaration claiming that it raised too many complex legal questions, including the differences between domestic legal systems applying either the principle of ius soli or ius sanguinis, that cannot be resolved by the declaration. ${ }^{20}$ Later on, this position was modified due to the fundamental importance of the right to a nationality.

17 The Universal Declaration of Human Rights, G.A. Res. 217A, 10 December 1948, Art. 15.

18 Declaration on the Rights of the Child, G.A. Res. 1386, 20 November 1959.

19 Id., Principle 3.

20 See G. Van Bueren, The International Law on the Rights of the Child, Kluwer Law International, The Hague, 1998, p. 366. See the remarks of Mr. Suphamonghon, the representative of Thailand. P.E. Veerman, The Rights of the Child and the Changing Image of Childhood, Martinus Nijhoff Publishers, Dordrecht \& Boston, 1992, p. 171. 
The Convention on the Reduction of Statelessness of $1961^{21}$ does not contain the right to a nationality. Nevertheless, Article 8, paragraph 1, prohibits the deprivation of nationality. Hence states may not deprive anyone of his or her nationality if such deprivation would render him or her stateless - save for a few exceptions. ${ }^{22}$ Remarkably, the draft convention had envisaged a general prohibition of deprivation, but during the debates states pressed the inclusion of several exceptions into the final text, which substantially weakened the prohibition. Still, there are important guarantees, namely that the exceptions can only be exercised in accordance with law, and states must provide the right to a fair hearing by a court or other independent body. ${ }^{23}$

The International Covenant on Civil and Political Rights of $1966^{24}$ does not contain the right to a nationality in general. Article 24, paragraph 3, only provides for the right to acquire a nationality, and only provides it to children. ${ }^{25}$ States agreed that every effort should be made to prevent the statelessness of children at the 17th and 18th meetings of the Third Committee of the UN General Assembly. ${ }^{26}$ This obviously represents a step back as compared to the Declaration on the Rights of the Child. While the declaration includes the right to a nationality of the child in general terms, the covenant only ensures the right to acquire a nationality - it does not offer protection against the loss of nationality. The drafters of the covenant believed that the taking over of the relevant principle from the Declaration on the Rights of the Child would not have been supported by states, as - as they claimed - it would have obliged states to grant nationality to children born in their territory. ${ }^{27}$ Nonetheless, this obligation would not exist even if the declaration was interpreted broadly. The Commission of Human Rights interpreted similarly the article and stated that Article 24, paragraph 3, of the covenant merely requires states to 'adopt every appropriate measure, both internally and in cooperation with other States, to ensure that every child has a nationality when he is born. ${ }^{28}$ The Commission on Human Rights also pointed out that the purpose of this article is to prevent a child from being afforded less protection by society and the State because he or she is stateless, rather than to afford an entitlement to a nationality of one's own choice. ${ }^{29}$ For that reason the body did not consider

211961 Convention on the Reduction of Statelessness, 989 UNTS 175.

22 Id., Art. 8, Paras. 1-3.

23 Id., Art. 8, Para. 4.

241966 International Covenant on Civil and Political Rights, 999 UNTS 171.

25 Id., Art. 24, Para. 3.

26 See A/C.3/SR.1172, A/C.3/SR.1177.

27 See J.E. Doek, 'The CRC and the Right to Acquire and to Preserve a Nationality', 25(3) Refugee Survey Quarterly (2006), p. 26.

28 See Human Rights Committee (35th session, 1989), General Comment 17, Article 24 Rights of the Child, Para. 8.

29 Human Rights Committee, Communication No. 1134/2002, Fongum Gorji-Dinka v. Cameroon, UN Doc. CCPR/C/83/D/1134/2002 (2005), Para. 4.10. 
demands by persons possessing a nationality to acquire a new nationality substantiated under Article 24, paragraph 3, on several occasions. ${ }^{30}$

Similarly to the Universal Declaration of Human Rights, the covenant fails to clarify which state specifically bears the responsibility to provide nationality. Therefore, it may not be claimed that it is the obligation of the state of birth to do so. ${ }^{31}$ Besides, the provision does not concern cases of change or loss of nationality, even if persons indeed of protection happen to be children. ${ }^{32}$

The Declaration on Social and Legal Principles relating to the Protection and Welfare of Children of $1986,{ }^{33}$ being a General Assembly resolution, is merely a recommendation. Article 8 of the declaration requires that ' $[\mathrm{t}]$ he child should at all times have [...] a nationality. ${ }^{34}$ In keeping with the Declaration of the Rights of the Child, the document involves the recognition of the right to acquire a nationality and the elimination of statelessness caused by the loss of nationality. It also prohibits the deprivation of nationality of children, except for cases when they acquire a new nationality. In other words, the declaration expressly acknowledges that children may be deprived of their previous nationality upon becoming a dual or multiple national.

Article 7 of the Convention on the Rights of the Child of $1989,{ }^{35}$ a human rights instrument with the highest number of states parties, stipulates that ' $\mathrm{t}$ ] he child shall be registered immediately after birth and shall have [...] the right to acquire a nationality'. The convention further requires that states 'shall ensure the implementation of these rights' and the implementation needs to be 'in accordance with their national law and their obligations under the relevant international instruments in this field in particular where the child would otherwise be stateless, ${ }^{36}$ Suffice it to note that this was the first human rights document to pay special attention to statelessness. The registration of children is usually a key element for the acquisition of nationality, thus the Committee on the Rights of the Child emphasised that states should make every necessary effort to register children after birth. ${ }^{37}$ The article reveals that states have a sovereign right to determine the conditions

30 Id., Human Rights Committee, Communication No. 820/1998, Mr. Keshva Rajan and Mrs. Sashi Kantra Rajan v. New Zealand, UN Doc. CCPR/C/78/D/820/1998 (2003), Para. 7.5.

31 See e.g. J.L. Blackman, 'State Successions and Statelessness: The Emerging Rights to an Effective Nationality under International Law', 19(3) Michigan Journal of International Law (1998), p. 1172; J.M.M. Chan, 'The Right to a Nationality as a Human Right. The Current Trend Towards Recognition', 12(1-2) Human Rights Law Journal (1991), p. 5.

32 See J. Crawford, 'Territorial Change and the Status of Inhabitants', XXVII(1) Seoul Law Journal (1986), pp. 48-49.

33 Declaration on Social and Legal Principles relating to the Protection and Welfare of Children, G.A. Res. 41/85, 3 December 1986.

34 Id., Art. 8.

351989 Convention on the Rights of the Child, New York, 1577 UNTS 3.

36 Id., Art. 7.

37 See Doek, 2006, p. 27. 
for the acquisition and loss of nationality, but states are limited by the international obligations undertaken concerning nationality including the enforcement of the requirement to eliminate the occurrence of statelessness. ${ }^{38}$ Hence, Article 7 does not prescribe the application of ius soli principle, but states parties shall provide the acquisition of nationality for children, in particular where they would otherwise be stateless, according to their relevant international obligations including the Convention on the Reduction of Statelessness of $1961 .^{39}$

In addition, Article 8 of the convention obliges states to respect the right of the child to preserve his or her identity, including nationality, name and family relations as recognized by law without unlawful interference. This right is safeguarded by the requirement that states parties must provide appropriate assistance and protection, with a view to speedily re-establish the identity of the child, if he or she is illegally deprived of some or all of the elements of his or her identity. The right to retain nationality offers protection against statelessness in lieu of the prohibition of arbitrary deprivation, albeit in a weaker fashion, as the obligation of states to take appropriate measures in cases of illegal deprivation is not sufficiently specified. Article 8 further implies that when his or her parents lose their nationality due to of a legal provision, an administrative act or any other reason, the child does not automatically lose his or her nationality, and may retain that, particularly if he or she would otherwise become stateless. ${ }^{40}$

The International Convention on the Protection of the Rights of All Migrant Workers and Members of Their Families of $1990^{41}$ contains the right to a nationality in general terms, but only for a special group of subjects. In keeping with the limited scope of the convention, Article 29 recognizes the right to a nationality of children of migrant workers in much the same spirit as the Universal Declaration of Human Rights provides that right to 'everyone'. The requirement of registration too affords protection to the child, similarly to the analogous stipulations of other instruments. ${ }^{42}$

The Convention on the Rights of Persons with Disabilities of $2006^{43}$ follows the pattern of Article 7 of the Convention on the Rights of the Child, when it recognizes the right to a nationality. As a result of the specialized nature of the convention, the bearers of that right under Article 18, paragraph 2, are children with disabilities, to whom the instruments

38 See I. Ziemele, State Continuity and Nationality: The Baltic States and Russia: Past Present and Future as Defined by International Law, Martinus Nijhoff Publishers, Leiden \& Boston, 2000, p. 283.

39 More detailed see S. Detrick, A Commentary on the United Nations Convention on the Rights of the Child, Martinus Nijhoff Publishers, The Hague, London, 1999, pp. 150-152.

40 See Doek, 2006, p. 30.

411990 International Convention on the Protection of the Rights of All Migrant Workers and Members of Their Families, 2220 UNTS 3.

42 Id., Art. 29.

432006 Convention on the Rights of Persons with Disabilities, 2515 UNTS 3. 
offers registration and acquisition of a nationality. ${ }^{44}$ The requirement of registration is phrased similarly to its earlier counterpart. The instrument also resembles the Convention on the Rights of the Child in that it only lays down the right to acquire a nationality.

\subsubsection{Regional Protection}

In Europe, the Convention for the Protection of Human Rights and Fundamental Freedoms of $1950^{45}$ contains neither the right to a nationality nor the prohibition of arbitrary deprivation of nationality. However, nearly four decades later, in April 1988, the Committee of Experts for the Development of Human Rights examined of the feasibility of incorporation of the right to a nationality into the convention by way of a questionnaire ${ }^{46}$ addressed to states parties. The survey revealed that European states had similar positions. There was widespread agreement that the draft should include the following elements: everyone has a right to a nationality; everyone has a right to acquire the nationality of the state in whose territory he or she was born, if he or she would otherwise become stateless; and no one can be arbitrarily deprived of his or her nationality or the right to change nationality. ${ }^{47}$ Although the envisaged regulation mostly conforms the prevailing domestic regulations of European states, there has not been any progress in the drafting of such a protocol to the convention since 1989. It appears that states are reluctant to extend the supervisory role of the European Court of Human Rights to matters of nationality.

The case-law of the court indicates that the judicial organ seeks to provide protection to individuals against the consequences of statelessness by invoking the right to respect for private and family life as enshrined in Article 8 of the convention. ${ }^{4}$ The respect for

44 Id., Art. 18, Para. 2.

451950 Convention for the Protection of Human Rights and Fundamental Freedoms, 213 UNTS 221.

46 Five main questions were raised for states in the questionnaire made by the Committee of Experts for the Development of Human Rights: 1. Is every stateless person born in the country entitled to acquire its nationality? 2. Is every person entitled to change his or her nationality? 3. Can any person be arbitrarily deprived of his or her nationality? 4. To what extent does a stateless adult have a right to acquire the nationality of the given state? What are the reasons not to ratify, inter alia, the United Nations Convention on the Reduction of Statelessness and, for those countries that have ratified them, have they encountered any difficulties in implementing these conventions? See Chan, 1991, p. 7.

47 For more see Chan, 1991, pp. 7-10.

48 Several documents include the protection of private and family life and the prohibition of interference with the privacy or the family of the individual. At the same time, most of these documents contain the right to a nationality; therefore, an interpretation similar to the case-law of the European Court of Human Rights is hardly conceivable. See e.g. The Universal Declaration of Human Rights, G.A. Res. 217A, 10 December 1948, Art. 16, Para. 3; 1966 International Covenant on Civil and Political Rights, 999 UNTS 171, Art. 17, Art. 23, Para. 1; 1989 Convention on the Rights of the Child, 1577 UNTS 3, Art. 8, Para. 1, Art. 16; 1969 American Convention on Human Rights, 1144 UNTS 123, Art. 17, Para. 1; African Charter on the Rights and Welfare of the Child, Addis Ababa, 11 July 1990, OAU Doc. CAB/LEG/24.9/49 (1990), Art. 10. Similarly to the European Convention on Human Rights, certain documents do not contain the right to a nationality, and include the protection of family life only. See 1966 International Covenant on Economic, Social and 
private and family life was first associated with the issues of statelessness in 1997. Even the European Commission of Human Rights had pointed out in a report that, notwithstanding the absence of the right to a nationality from the convention, statelessness, at least to some extent, affects and perturbs the private and family life of the individual. ${ }^{49}$ The European Convention on Nationality, which was concluded in the same year, recalled Article 8 in its preamble in the following manner: '[a]ware of the right to respect for family life as contained in Article 8 of the Convention for the Protection of Human Rights and Fundamental Freedoms'. ${ }^{50}$ This reference also suggests the applicability of the said article in relation to statelessness. Two years later, the European Court of Human Rights remarked that

[a]lthough right to a citizenship is not as such guaranteed by the Convention or its Protocols [...], the Court does not exclude that an arbitrary denial of a citizenship might in certain circumstances raise an issue under Article 8 of the Convention because of the impact of such a denial on the private life of the individual $[\ldots] .^{51}$

Hence an arbitrary deprivation of nationality may result in a violation of the right to respect for private and family life as provided for in the convention, ${ }^{52}$ but it should be emphasized that such a violation can occur only if the consequences of deprivation affect the life of the individual. The court subsequently reaffirmed this dictum, ${ }^{53}$ often with regard to persons, who had been rendered stateless by state succession. ${ }^{54}$ In these cases the individuals had spent most of their lives in the given territory, developed personal, social, cultural, linguistic,

Cultural Rights, 993 UNTS 3, Art. 10; 1981 African Charter on Human and Peoples' Rights, 1520 UNTS 217, Art. 18.

49 Kafkasli contre la Turquie, Appl. No. 21106/92, Report of the European Commission of Human Rights, 1 July 1997, Para. 33.

501997 European Convention on Nationality, 2135 UNTS 213. A reference to its effect on the interpretation of the convention see T. Kerikmäe, 'European Convention on Nationality and States' Competence: The Issue of Human Rights', II Juridica International (Law Review - University of Tartu) (1997), p. 26.

51 Karassev v. Finland, ECHR, Appl. No. 31414/96, Decision as to the admissibility of 12 January 1999, Part The Law, Para. 1.b).

52 A. Komanovics, 'State Succession, Nationality, and Human Rights. Application of Article 8 of the European Convention on Human Rights to Nationality Issues', in R.I. Motica et al. (Eds.), Biennal International Conference, Timişoara, Universul Juridic, Bucureşti, 2011, p. 831.

53 Slivenko and Others v. Latvia, ECHR, Appl. No. 48321/99, Decision as to the admissibility of 12 January 1999, Para. 77; Kuduzović v. Slovenia, ECHR, Appl. No. 60723/00, Decision as to the admissibility of 17 March 2005, Part The Law, Para. 2; Kurić and Others v. Slovenia, ECHR, Appl. No. 26828/06, Chamber Judgment of 13 July 2010, Para. 353. For a detailed analysis of Slivenko and Others v. Latvia and Kurić and Others v. Slovenia see Komanovics, 2011, pp. 824-831.

54 Kuduzović v. Slovenia, ECHR, Appl. No. 60723/00, Decision as to the admissibility of 17 March 2005, Part The Law, Para. 2; Kurić and Others v. Slovenia, ECHR, Appl. No. 26828/06, Chamber Judgment of 13 July 2010, Para. 353. 
economic bonds, established families, and their children had already been born in that territory. ${ }^{55}$ As regards the emergence of the so-called 'erased' persons in the wake of postsuccession legislative measures in Slovenia, the court found that these measures had not been in conformity with Article 8, particularly in those instances, when they caused statelessness. ${ }^{56}$ Upon the determination of a violation of Article 8, the court also recalled the norms of international law, which call for the elimination of statelessness in cases of state succession. ${ }^{57}$ The court refrained in these cases from expressly recognizing the right to a nationality of the persons concerned (surely it could not have done that), but extended the right to respect for private and family life to persons, who had become stateless or foreigners as a result of state succession with a view to protect them from adverse consequences, such as expulsion. ${ }^{58}$ The settlement of the status of such persons in conformity with Article 8 might as well enable them to acquire nationality by ordinary or preferential naturalization.

Three important treaties on nationality in the European continent have, to some extent, remedied this shortcoming. The Convention to Reduce the Number of Cases of Statelessness, concluded in Bern, in 1973, ${ }^{59}$ under the aegis of the International Commission on Civil Status, an inter-governmental organization, stipulates in Article 1 that '[a] child whose mother holds the nationality of a Contracting State shall acquire that nationality at birth if he or she would otherwise have been stateless'. This content of this provision is closely related to human rights instruments, and though it does not use the term 'right', it clearly recognizes the right to a nationality of the child. Similarly to the International Covenant on Civil and Political Rights and the Convention on the Rights of the Child, this convention does not make mention of the change or retaining of nationality either. Furthermore, the quoted provision fails to embrace children, whose mothers are stateless at the time of birth.

The European Convention on Nationality of $1997,{ }^{60}$ adopted by the Council of Europe, guarantees - similarly to the Universal Declaration of Human Rights - in Article 4, among

55 Kurić and Others v. Slovenia, ECHR (2012) Appl. No. 26828/06, Grand Chamber Judgment of 26 July 2012 , Para. 336; Slivenko v. Latvia, ECHR (2003) Appl. No. 48321/99, Grand Chamber Judgment of 9 October 2003, Para. 96.

56 Kurić and Others v. Slovenia, ECHR (2012) Appl. No. 26828/06, Grand Chamber Judgment of 26 July 2012 , Paras. 337, 359.

57 Kurić and Others v. Slovenia, ECHR (2010) Appl. No. 26828/06, Chamber Judgment of 13 July 2010, Para. 376; Kurić and Others v. Slovenia, ECHR (2012) Appl. No. 26828/06, Grand Chamber Judgment of 26 July 2012, Para. 338.

58 In certain cases, the status of stateless individuals was settled, and their expulsion was avoided. See Sisojeva and Others v. Latvia, ECHR (2007) Appl. No. 60654/00, Grand Chamber Judgment of 15 January 2007; Kaftailova v. Latvia, ECHR (2007) Appl. No. 59643/00, Grand Chamber Judgment of 7 December 2007; Shevanova v. Latvia, ECHR (2007) Appl. No. 58822/00, Grand Chamber Judgment of 7 December 2007.

59 Bern Convention of the International Commission of Civil Status to Reduce the Number of Cases of Statelessness, Bern, 13 September 1973.

601997 European Convention on Nationality, 2135 UNTS 213. 
the principles concerning nationality, the right to a nationality, according to which 'everyone has the right to a nationality'. Principles in the convention includes the avoidance of statelessness and the prohibition of arbitrary deprivation of nationality, as well. Nevertheless, the convention permits states to decide on the loss of nationality in cases of voluntary acquisition of another nationality, unless the person concerned would otherwise be stateless.

The preamble and the commentary of the Council of Europe Convention on the Avoidance of Statelessness in relation to State Succession of $2006^{61}$ both recall the right to a nationality as contained in the Universal Declaration of Human Rights and the European Convention on Nationality. The convention recognizes the right to a nationality in cases of state succession only. Article 2 ensures that individuals having the nationality of the predecessor state at the time of the State succession 'ha[ve] the right to the nationality of a State concerned', if they have or would become stateless as a result of the State succession. The provision reveals that the aim of the convention is to eliminate statelessness caused by state succession, and does not affect cases of statelessness already existing in the predecessor state.

In the American continent the American Declaration of the Rights and Duties of Man of $1948^{62}$ is a non-binding document, ${ }^{63}$ which, as has been mentioned, was adopted eight months before the Universal Declaration of Human Rights. According to Article XIX, '[e]very person has the right to the nationality to which he is entitled by law and to change it' and 'if he so wishes, for the nationality of any other country that is willing to grant it to him'. As it has been adequately claimed, this article offers nothing else than persons should possess a nationality under any domestic law, ${ }^{64}$ and as such, it only lays down the right to acquire and change nationality as prescribed by law. ${ }^{65}$ However, the Inter-American Commission on Human Rights stated that the deprivation of nationality during war is an unwarranted punishment, and violates Article $19 .^{66}$

The American Convention on Human Rights of $1969^{67}$ was the first to spell out, upon recognizing the right to a nationality, which state is ultimately responsible to provide nationality to avoid statelessness. Nationality matters are regulated by Article 20 of the

612006 Council of Europe Convention on the Avoidance of Statelessness in relation to State Succession, 2650 UNTS 305.

62 American Declaration of the Rights and Duties of Man, O.A.S. Res. III, Ninth International Conference of American States, Bogotá, 2 May 1948.

63 On the legal status of the document, see T. Buergenthal, 'The Revised OAS Charter and the Protection of Human Rights', 69(4) American Journal of International Law (1975), pp. 828-836.

64 See e.g. P. Sieghart, The International Law of Human Rights, Clarendon Press, Oxford, 1984, p. 260.

65 For a similar formula see ASEAN Human Rights Declaration, Phnom Penh, 18 November 2012.

66 See Inter-American Commission on Human Rights, Third Report on the Situation of Human Rights in Chile, OEA/Ser.L/V/II.40, Doc. 10. 1977. pp. 33-34.

671969 American Convention on Human Rights, 1144 UNTS 123. 
convention. ${ }^{68}$ Paragraph 1, granting the right to a nationality for everyone, and paragraph 3 , prohibiting the arbitrary deprivation of nationality or the right to change nationality echo the wording of the Universal Declaration of Human Rights. Paragraph 2 declares the right of every person to the nationality of the state in whose territory he or she was born, if he or she is not entitled to any other nationality. This provision is at times recalled as an instrument of the elimination of statelessness evolving at birth, ${ }^{69}$ but it should be noted that it also protects persons, who subsequently become stateless by obliging, as a last resort, the state of birth to provide nationality. However, it is worth mentioning that Article 20 does not protect stateless individuals whose place of birth is unknown. For example, the place of birth of a foundling is not to be automatically presumed to be in the state, where he or she was found.

The African Charter on the Rights and Welfare of the Child of $1990^{70}$ also contains a clear obligation to provide nationality, along with the designation of state which is ultimately obliged to do so in order to avoid the statelessness of the child. According to Article 6 of the charter '[e]very child shall be registered immediately after birth' and '[e]very child has the right to acquire nationality'. The necessity of registration of children is too regulated by the Article 7, paragraph 1, of the Convention of the Rights of the Child, with the difference that it does not contain the condition 'immediately'. The importance of registration and the 'strong and direct link between birth registration and nationality' was highlighted by the African Committee of Experts on the Rights and Welfare of the Child, ${ }^{71}$ as children may become stateless without birth registration, if their place of birth or descent cannot be proven. Besides, the Committee stated that the requirement of birth registration in the charter 'is not only limited to passing laws (and policies), [...] but also extends to addressing all de facto limitations and obstacles to birth registration'. ${ }^{72}$

The charter restricts the scope of the right to a nationality to children and to the acquisition of a nationality. The right of the child to acquire a nationality reflects the provisions of Article 24, paragraph 3, of the International Covenant on Civil and Political Rights and Article 7, paragraph 1, of the Convention on the Rights of the Child. The expression 'from his birth' is not added to the right to acquire a nationality, but the African

68 See e.g. the violation of the right to a nationality and the prohibition of arbitrary deprivation of nationality Baruch Ivcher Bronstein v. Peru, Inter-American Court of Human Rights, Judgment of 6 February 2001, Paras. 95-97.

69 R. Donner, The Regulation of Nationality in International Law, Transnational Publishers, Inc., New York, 1994 , p. 230.

70 African Charter on the Rights and Welfare of the Child, Addis Ababa, 11 July 1990, OAU Doc. CAB/LEG/24.9/49 (1990).

71 African Committee of Experts on the Rights and Welfare of the Child, Communication No. Com/002/2009, Institute for Human Rights and Development in Africa (IHRDA) and Open Society Justice Initiative on Behalf of Children of Nubian Descentin Kenya v. The Government of Kenya, Decision of 22 March 2011, No. 002/Com/002/2009, Paras. 38, 42.

72 Id., Para. 40. 
Committee of Experts on the Rights and Welfare of the Child declared that 'as much as possible, children should have a nationality beginning from birth', as the purpose of Article 6 is to prevent and reduce statelessness, and the ensuring of acquisition of nationality upon application after reaching eighteen years of age, cannot be seen as an effort to comply with the obligation indicated in the provision. ${ }^{73}$

Article 6, paragraph 4, of the charter is particularly important, which - similarly to Article 20, paragraph 4, of the American Convention on Human Rights - provides, as a last resort, the right to a nationality on the basis of the ius soli principle to eliminate statelessness. Nevertheless, it has a more restricted scope than the convention, as the bearer of the right is the child - in conformity with the subject-matter of the charter - and the ensured right is the right to acquire a nationality. But the charter goes beyond the American Convention on Human Rights by setting out additional obligations for states in order to ensure that right. It is also worth mentioning that the right to acquire a nationality provided on the basis of the ius soli principle does not imply the obligation to generally apply this principle. The principle needs to be applied, if the child born in the territory is not able to acquire another nationality, and would otherwise be stateless. ${ }^{74}$ Remarkably, states undertake to ensure that their constitutional legislation recognizes this principle. According to the interpretation by the African Committee of Experts on the Rights and Welfare of the Child, the phrase 'undertake to ensure' implies an obligation of result, that is, states need to take all necessary measures to prevent the child from becoming stateless. ${ }^{75}$ Thus, the charter is unique among human rights documents, as it prescribes the application of the ius soli principle, as a last resort, to avoid statelessness, and spells out further obligations for states to implement it.

A resolution of the Conference on Security and Co-operation in Europe, ${ }^{76}$ adopted at a meeting in July 1992 as a soft law document, likewise contains the right to a nationality and the prohibition of arbitrary deprivation, ${ }^{77}$ similarly to the Universal Declaration of Human Rights. It requires states to govern all aspects of nationality by the process of law, and to take all appropriate measures not to increase statelessness. Measures taken by states should be 'consistent with their constitutional framework', which slightly weakens the requirement. It should be noted that this resolution is a political undertaking of the fiftytwo states participating at the summit, which was attended - among others - by the successor states of the Soviet Union. ${ }^{78}$

73 Id., Paras. 42, 44.

74 Id., Paras. 50-51.

75 Id., Para. 52.

76 The name of the Conference on Security and Co-operation in Europe (CSCE) was changed to Organization for Security and Co-operation in Europe (OSCE) at its summit in Budapest, in December 1994. Budapest Summit Declaration. Towards a Genuine Partnership in a New Era, Budapest, 6 December 1994, Para. 3.

77 Declaration and Decisions from the Helsinki Summit, Helsinki, 10 July 1992, Part VI, Paras. 55-57.

78 For more see Donner 1994, p. 241. 
Three years later, the right to a nationality and the prohibition of deprivation of nationality was included into the Commonwealth of Independent States Convention on Human Rights and Fundamental Freedoms of $1995 .^{79}$ This right appears in the English text of the document without an indefinite article and with the expression 'citizenship', which does not reveal substantial differences as compared to the meaning of the formula of the Universal Declaration of Human Rights. The prohibition of arbitrary deprivation of nationality also reflects the wording of the declaration, since the convention covers the right to both retain and change nationality.

The initial version of the Arab Charter on Human Rights was adopted on 15 September 1994, but never entered into force. The charter did not include the right to a nationality; it only contained the prohibition of arbitrary deprivation of the original nationality and the deprivation of the right to acquire another nationality without a legally valid reason. ${ }^{80}$ The Council of the League of Arab States adopted resolutions in 2002 concerning the review of the charter, as it did not conform to human rights standards. ${ }^{81}$ The revised Arab Charter on Human Rights was adopted on 22 May 2004, ${ }^{82}$ and now includes the right to a nationality in Article 29. Paragraph 1 declares the right to a nationality in general, for everyone, and contains the epithets 'unlawfully' and 'arbitrarily' as alternatives with regard to the deprivation of nationality. The right of the child to acquire the nationality of his or her mother in paragraph 2 points towards the prohibition of discrimination. ${ }^{83}$ Paragraph 3 further states that ' $[n]$ o one shall be denied the right to acquire another nationality in accordance with the applicable legal procedures of his country.'

The African Charter on Human and Peoples' Rights of $1981^{84}$ does not make mention of the right to a nationality, and even its protocol on the rights of women in Africa of $2003^{85}$ recalls it in the context of marriage only. The purpose of this provision is to ensure that marriage does not affect the nationality of a woman against her will. Therefore, its content encompasses only the right to retain nationality and the right to acquire a nationality, with the latter being limited to the nationality of the husband. ${ }^{86}$

79 Commonwealth of Independent States Convention on Human Rights and Fundamental Freedoms, Minsk, 26 May 1995, Art. 24.

80 Arab Charter on Human Rights, Cairo, 15 September 1994, Art. 24.

81 For more see M. Rishmawi, 'The Revised Arab Charter on Human Rights: A Step Forward?', 5(2) Human Rights Law Review (2005), pp. 361-362.

822004 Arab Charter on Human Rights, 12 Intl. Human Rights Rep. 893.

83 Cf. 1979 Convention on the Elimination of All Forms of Discrimination against Women, 1249 UNTS 13, Art. 9, Para. 2.

841981 African Charter on Human and Peoples' Rights, 1520 UNTS 217.

85 Protocol to the African Charter on Human and Peoples' Rights on the Rights of Women in Africa, Maputo, 11 July 2003.

86 Id., Art. 6. 
The Covenant on the Rights of the Child in Islam, ${ }^{87}$ concluded in June 2005, under the aegis of the Organization of the Islamic Conference also includes a provision concerning nationality in Article $7{ }^{88}$ Given the subject of the charter, paragraph 1 designates the child as the beneficiary of 'hav[ing] his [or her] nationality determined' rather than the right to a nationality. Besides, this paragraph includes the necessity of registration of children with the authorities concerned. According to paragraph 2, states 'shall safeguard the elements of the child identity, including his/her [...] nationality [...], in accordance with their domestic laws', and states 'shall make every effort to resolve the issue of statelessness for any child born on their territories or to any of their citizens outside the territory.' Therefore, paragraph 2 excludes a potential interpretation of the curiously worded paragraph 1 that it does not refer to the right to acquire a nationality. The aim of the drafters seems to be obvious, namely to ensure the right to a nationality for children by virtue of both the ius soli and ius sanguinis principles. In case of its entry into force after the twentieth ratification, ${ }^{89}$ the covenant will offer an appropriate protection to children against statelessness.

\subsection{Assessment of the Right to a Nationality}

When analysing the content of the right to a nationality, one needs to make a distinction between the right to a nationality of every person and that of children in view of the divergences of various documents. The provision of the Universal Declaration of Human Rights, which states that ' $[\mathrm{e}]$ veryone has a right to a nationality', ${ }^{90}$ was subsequently taken over by several documents, such as the American Convention on Human Rights, the Arab Charter on Human Rights and the European Convention of Nationality. The records of debates that took place during the drafting of the Universal Declaration of Human Rights suggest that the purpose of this provision was to ensure protection against statelessness, ${ }^{91}$ but the obscure phrasing leaves room for divergent interpretations. The indefinite article ' $a$ ' before the expression 'nationality' is similar to the numeral 'one' in certain languages - for example, 'une' in French stands for either an indefinite article or a numeral. The real content of the paragraph is expressed exactly by the expression 'valamely' in Hungarian translation. Due to the fact that the purpose of regulation was undoubtedly to eliminate statelessness, neither a human right of dual nationality, ${ }^{92}$ nor a prohibition of dual

87 Covenant on the Rights of the Child in Islam, Sana'a, 28-30 June 2005. The covenant was adopted by the 32nd Islamic Conference of Foreign Ministers held between 28 and 30 June 2005.

88 Id., Art. 7, Paras. 1-2.

89 Id., Art. 23, Para. 1.

90 Universal Declaration of Human Rights, G.A. Res. 217A, 10 December 1948, Art. 15, Para. 1.

91 Verdoodt, 1964, pp. 156-161.

92 On the contrary see e.g. Spiro, 2010, pp. 111-130. 
nationality ${ }^{93}$ can be deduced from the provision under consideration. Through this purpose, it can be accepted, that the right to a nationality includes the right to acquisition and retention of nationality. ${ }^{94}$ Notwithstanding that scholarly opinions significantly differ concerning the right to change nationality, as that particular right is related to the disposition of nationality rather than to the elimination of statelessness.

Having analysed the regulation of the right of the child to a nationality, it may be pointed out that in the legally binding documents its content usually covers the acquisition of a nationality only, and aims to eliminate statelessness emerging at birth. The Convention on the Rights of the Child is a notable exception, for it includes not only the right to acquire, but also the right to retain a nationality; thus it even provides protection to children against becoming stateless at a later stage. This exceptional rule needs to be evaluated in light of the fact that the number of states parties of the convention exceeds 190, and as such, it is applicable in a much wider sphere than the above-mentioned and more frequent solution. In addition, the previous remarks concerning the indefinite article also hold true for the relevant right of the child.

The main shortcoming of the right to a nationality is that documents usually do not designate the state that has an obligation to provide nationality for the individual. This substantially reduces the significance of that right, as states may easily shift onto one another the obligation of providing nationality. Thus, the right to a nationality may become an empty shell, and the efficiency of any reference to that right may be rendered dubious. ${ }^{95}$ Only two documents remedy this shortcoming. The American Convention on Human Rights and the African Charter on the Rights and Welfare of the Child obliges, as a last resort, the state of birth to provide nationality by applying the ius soli principle - the former for everyone, the latter for children. It is worth mentioning that even these documents cannot protect stateless persons, for example foundlings, whose place of birth is not determinable.

The prohibition of deprivation of nationality cannot be directly deduced from the right to a nationality, albeit examples can be found in the practice of the Inter-American Commission on Human Rights. The prohibition of deprivation is closely linked to the right to a nationality, and it generally follows the right to a nationality in international instruments. The epithets 'arbitrary' and 'unlawfully' are frequently attached as attributes to the prohibition of deprivation, but their interpretation gives rise to debates. 'Arbitrary' as an attribute is used by the Universal Declaration of Human Rights, the American Convention on Human Rights, the Arab Charter on Human Rights and the European Convention on

93 On the contrary see e.g. Griffin, 1966-1967, pp. 57-64.

94 Chan, 1991, pp. 1-2, 3.

95 For a similar opinion see H.F. Van Pahuys, The Role of Nationality in International Law, Leyden, A.W. Sijthoff, 1959, p. 222. 
Nationality, while 'unlawful' appears in the Convention on the Rights of Child and in the Arab Charter on Human Rights - in the latter alongside 'arbitrary'.

The Universal Declaration of Human Rights includes the prohibition of arbitrary deprivation of nationality without offering a definition of arbitrariness. However, the drafting process reveals that the drafters reckoned the elimination of statelessness as the main purpose of the right to a nationality. The statement that a deprivation of nationality is arbitrary, if it results in statelessness can be deduced from the said purpose of the declaration. Therefore, if the right to a nationality is considered as a fundamental human right, any deprivation of nationality resulting in statelessness can be labelled as 'arbitrary', as it would be blatantly incompatible with the purposes of the declaration. It should be recalled that the Convention on the Reduction of Statelessness of 1961 stipulates that states shall not deprive a person of his or her nationality, if such deprivation would render him or her stateless. ${ }^{96}$ The text of the prohibition, however, does not contain any epithets. Although there are some exceptions from the above mentioned statement. According to the report of the UN Secretary-General on human rights and arbitrary deprivation of nationality of 14 December 2009, a deprivation resulting in statelessness would not be arbitrary if it would 'serve a legitimate purpose that is consistent with international law', or would 'compl[y] with the principle of proportionality'. ${ }^{97}$ For example, a deprivation resulting in statelessness would observe the principle of proportionality, if the 'nationality has been obtained by deception' as indicated by the Court of Justice of the European Union in the Rottmann case. ${ }^{98}$

Consequently, the prohibition of arbitrary deprivation of nationality does not cover dual or multiple nationals, who will possess at least one nationality after losing a nationality through deprivation. This can be illustrated by Article 7 of the European Convention of Nationality that, in addition to the prohibition of arbitrary deprivation of nationality in Article 4(c), permits states to provide for the loss of nationality in their domestic enactments either ex lege, or at the initiative of the state, in case a person voluntarily acquires another nationality. ${ }^{99}$ The Explanatory Report of the convention also refers to Article 7 for an exhaustive list of grounds for deprivation, which likewise proves that an ex lege loss of nationality in consequence of a voluntary acquisition of another nationality cannot be

961961 Convention on the Reduction of Statelessness, 989 UNTS 175, Art. 8, Para. 1.

97 Human Rights and Arbitrary Deprivation of Nationality, Report of the Secretary-General, 14 December 2009. UN Doc. A/HRC/13/34. Paras. 25, 27, 59 See also Arbitrary Deprivation of Nationality, Report of the Secretary-General, 26 January 2009, UN Doc. A/HRC/10/34, Para. 49. (It is worth mentioning that the Human Rights Council regularly deals with various issues concerning nationality, such as the right to a nationality and arbitrary deprivation of nationality, for more see www.ohchr.org/EN/HRBodies/HRC/Pages/ HRCIndex.aspx.)

98 Judgment of 2 March 2010 in Case C-135/8, Rottmann v. Freistaat Bayern [1976] ECR, Para. 59.

991997 European Convention on Nationality, 2135 UNTS 213, Art. 4(c), Art. 7, Para. 1(a). 
deemed arbitrary. ${ }^{100}$ The Declaration on Social and Legal Principles relating to the Protection and Welfare of Children of 1986 also mentions the acquisition of a new nationality- and the dual or multiple nationality of the child - as an exception to the prohibition of deprivation of nationality of the child. ${ }^{101}$ In other words, it permits the deprivation of the previous nationality. Since the prohibition of the deprivation has no epithet in the declaration, this prohibition is broader than the prohibition of arbitrary deprivation. Therefore, the deprivation of nationality of dual nationals obviously cannot be labelled as arbitrary. In addition, the above-mentioned Explanatory Report to the European Convention on Nationality and the report of the UN Secretary-General give guidelines concerning the prevention of arbitrary deprivation of nationality.

According to these documents, the deprivation is arbitrary, if it is not foreseeable, proportional or prescribed by law, or if it is based on discrimination. ${ }^{102}$ Furthermore, the deprivation is also prohibited, if the person concerned would thereby become stateless, with the exception of the cases of 'acquisition of the nationality [...] by means of fraudulent conduct, false information or concealment of any relevant fact attributable to the applicant'. As regards the procedural safeguards, '[s]tates are [...] expected to observe minimum procedural standards in order to ensure that decisions on nationality matters do not contain any element of arbitrariness', ${ }^{103}$ so 'decisions relating to nationality shall contain reasons in writing and shall be open to an administrative or judicial review. ${ }^{104}$ In addition, arbitrariness was defined by the International Court of Justice as 'substituted for' or 'opposed to' the rule of law. ${ }^{105}$

The prohibition of denying the right to change nationality in the Universal Declaration of Human Rights and in the American Convention on Human Rights entails the prohibition of deprivation of both the right to renounce a nationality and to acquire another nationality. It cannot be construed, however, as a prohibition of deprivation of and a right to retain the former nationality, not to mention that the expression 'change' suggests the loss of that nationality.

In sum, it may be declared that the inherent vagueness and shortcomings of the right to a nationality considerably decrease the effectiveness of the protection it affords, and

100 Explanatory Report to the European Convention on Nationality. Available at http://conventions.coe.int/ Treaty/en/reports/html/166.htm, Para. 36.

101 Declaration on Social and Legal Principles relating to the Protection and Welfare of Children, G.A. Res. 41/85, 3 December 1986, Art. 8.

102 Explanatory Report to the European Convention on Nationality, Paras. 35-37; Human Rights and Arbitrary Deprivation of Nationality, Report of the Secretary-General, 14 December 2009, Paras. 22-46.

103 Human Rights and Arbitrary Deprivation of Nationality, Report of the Secretary-General, 14 December 2009. UN Doc. A/HRC/13/34. Para. 43.

104 Explanatory Report to the European Convention on Nationality, Para. 37.

105 Asylum Case (Colombia v. Peru), Judgment of 20 November 1950, 1950 ICJ Rep. 266, at 284; Case concerning Elettronica Sicula S.p.A. (ELSI) (United States of America v. Italy), Judgment of 20 July 1989, 1989 ICJ Rep. 15 , at 76, Para. 128. 
exposes its realization to the will of states. However, the elimination and reduction of statelessness usually become state interest due to problems originating from the status of stateless persons. Besides, provisions supplementing the right to a nationality concerning the prohibition of deprivation may offer appropriate protection against statelessness for individuals possessing a nationality.

According to Hersch Lauterpacht, 'nationality may not be a 'natural' or 'inalienable' right. Its importance is conditioned by the existence of sovereign States claiming to be the indispensable link between the individual and international law. ${ }^{, 106}$ The international legal personality of the individual is known not to depend on nationality. ${ }^{107}$ Statelessness, therefore, should be eliminated because of problems that stateless individuals and their receiving states need to solve, rather than the legal personality of such individuals. In order to enhance the protection of stateless individuals, it is worth to consider Lauterpacht's proposal, which advocates the granting of nationality by the state of birth as a last resort and the preconditioning of the acquisition of a new nationality for the deprivation of the previous nationality. ${ }^{108}$

106 H. Lauterpacht, International Law and Human Rights, Archon Books, London, 1968, p. 347.

107 Suffice is to mention the Art. 1 of the Convention for the Protection of Human Rights and Fundamental Freedoms, according to which everyone within the jurisdiction of contracting parties - regardless of his or her nationality or statelessness - may submit an application to the European Court of Human Rights. See e.g. Sisojeva and Others v. Latvia, ECHR, Appl. No. 60654/00, Grand Chamber Judgment of 15 January 2007; Kaftailova v. Latvia, ECHR (2007) Appl. No. 59643/00, Grand Chamber Judgment of 7 December 2007. Applicant were stateless in these cases. See also P. Weis, Nationality and Statelessness in International Law, Stevens \& Sons Ltd., London, 1956, pp. 258-259.

108 Hersch Lauterpacht proposed the following provision: 'Every person shall be entitled to the nationality of the State where he is born unless and until on attaining majority he declares for the nationality open to him by virtue of descent. No person shall be deprived of his nationality by way of punishment or deemed to have lost his nationality except concurrently with the acquisition of a new nationality. The right of emigration and expatriation shall not be denied.' Lauterpacht, 1968, p. 346. 
